\title{
PENGGUNAAN JARGON GAME ONLINE MOBILE LEGEND PADA ANAK REMAJA KARANG TARUNA PLUTO DALAM 2 PISANGAN TANGERANG SELATAN (TINJAUAN SOSIOLINGUISTIK)
}

\author{
Dihan Saidul Yamin ${ }^{1}$, Ilhamsyah ${ }^{2}$ dan Irfan Hafizh Izzatullah ${ }^{3}$
}

Universitas Pamulang 1,2,3

dihansaidulyamin@gmail.com ${ }^{1}, \underline{\text { ilhamsyaaaah27@gmail.com² }}$ dan $\underline{\text { irfanhafizh99@gmail.com }}$

\begin{abstract}
ABSTRAK
Pada penelitian kali ini bermaksud untuk menguraikan serta mengetahui motif dan arti khusus dari jargon yang sering dituturkan oleh para remaja karang taruna di Pluto Dalam 2 Pisangan Tangerang Selatan dalam memainkan game online Mobile Legend, karena pada kenyataannya game online yang menjamur saat ini sering kali memunculkan banyak kosakata atau istilah-istilah baru yang hanya dapat dipahami dan diketahui oleh suatu komunitas maupun kelompok sosial masyarakat tertentu. Penggunaan ragam bahasa jargon dalam game online Mobile Legend ini bermaksud untuk memudahkan komunikasi sekaligus juga untuk memberikan kode atau isyarat ketika memainkan game tersebut, agar lebih mudah dan efektif ketika diucapkan. Dalam penerapannya, jargon hanya dibatasi sesuai daerah saja, sesuai kelompok maupun instansi, dan juga individu yang memiliki ciri khas jargon yang mereka pahami dan sudah disepakati bersama. Pengkajian kini memakai metode observasi dan metode deskriptif kualitatif. Objek-objek yang dikaji dalam riset kali ini adalah para remaja karang taruna Pluto Dalam 2 Pisangan Tangerang Selatan. Metode observasi yang kami lakukan yaitu bertemu dengan beberapa remaja yang memang gemar dan sedang memainkan game online Mobile Legend. Proses pemungutan data kami lakukan memakai teknik simak, teknik wawancara dan teknik libat cakap melalui tatap muka secara langsung dan kami juga merekam ucapan yang mereka tuturkan melalui alat perekam handphone. Pengumpulan data jargon kami cantumkan berupa untaian kata-kata dan frasa baik bahasa Indonesia maupun bahasa asing yang selanjutnya akan kami artikan makna khusus dari data jargon yang kami dapatkan. Dari hasil data penelitian kami menemukan data jargon sebanyak 17 data di antaranya: retri indomaret, noob, di gendong, foto bareng, no flicker, nggak ada obat, mabar, tank, tower, monster hutan, tremor, kena mental, sergapan, ultimate, farming, adu mekanik, dan combo. Bersumber pada hasil data penelitian yang sudah kami lakukan dapat diberi simpulan bahwa penggunaan jargon hanya dipakai pada saat memainkan game tersebut, baik melalui komunikasi dua arah maupun komunikasi jarak jauh melalui telepon suara di dalam game, kemudian ketika sedang tidak memainkan game tersebut jargon tidak dipakai.
\end{abstract}

Kata kunci: sosiolinguistik, variasi bahasa, jargon.

PENDAHULUAN

Dalam proses kehidupan bahasa manusia yang dipakai setiap hari, bahasa menyandang peranan yang cukup penting dalam bersosialisasi dan berkomunikasi antar sesama manusia entah itu secara satu arah atau dua arah. Selain dipakai untuk berkomunikasi, bahasa dapat digunakan sebagai jembatan antara pemakai bahasa dengan ilmu pengetahuan. Bagi seorang pendidik dan peserta didik, bahasa dijadikan sebagai jembatan karena bahasa menghubungkan kedua belah pihak dalam menerima dan menyampaikan informasi. Ilmu pengetahuan sampai kepada orang lain apabila pemakai bahasa yang bersangkutan menggunakan bahasa yang komunikatif. Itulah sebabnya bahwa bahasa dapat dinyatakan untuk menyebarluaskan ilmu pengetahuan, teknologi, dan seni (Ramadansyah, 2010).

Melalui bahasa itu pula tercipta suatu rasa keakraban, kebersamaan, dan dapat memupuk rasa kekeluargaan. Selain itu, rasa kesetiakawanan masyarakat bisa dirasakan oleh pemakai bahasa jika 
bahasa yang digunakan secara santun. Bahasa juga digunakan oleh manusia sebagai sarana mengekspresikan diri dan sebagai komunikasi antar kelompok. Pemakaian bahasa yang baik dan santun selain menjadi cermin pribadi yang unggul juga sebagai sarana komunikasi manusia untuk menyampaikan gagasan, pikiran, berbuat sesuatu, bertindak, dan berperilaku. Bahasa dikatakan baik apabila pemakai bahasa tersebut bisa menerapkannya secara tepat dan serasi sesuai dengan situasi, kondisi, tingkat pendidikan, pekerjaan, dan lingkungan tempat tinggal.

Berkaitan dengan bahasa sebagai komunikasi yang telah disebutkan di atas, menurut Finocchiaro (dalam Alwasilah, 1985: 2) bahasa termasuk satu simbol vokal yang arbitrer yang sukasuka, menguatkan segala macam orang di suatu kebudayaan yang eksklusif, atau individu lain yang sudah mendalami sistem kebudayaan tersebut secara sungguh-sungguh sekaligus juga untuk berinteraksi, bersosialisasi atau berkomunikasi. Lebih lanjut lagi Sapir mengemukakan bahwa ujaran bahasa adalah kegiatan manusia yang bervariasi tanpa batas yang dapat ditentukan selagi kita beralih dari satu kelompok sosial ke kelompok sosial yang lain, karena ujaran tersebut betul-betul merupakan dari warisan historis kelompok itu sendiri, dan produk pemakaian sosial yang berlangsung lama (Alwasilah, 1985).

Dalam kegiatan penggunaan bahasa, maka hal ini tidak terlepas dari ilmu linguistik (bahasa) yang menjadikan bahasa sebagai pusat kajiaannya. Menurut Verhaar kata "linguistik" bermula-mula dari kata Latin "lingua" yang berarti "bahasa". Tapi di suatu masyarakat "roman" yaitu bahasa yang berawal dari negara Latin masih ada kata-kata yang sebentuk dengan bahasa Latin itu, yaitu "langue" dan "langage" dalam bahasa Prancis, dan "lingua" dari bahasa Italia. Sementara itu kata language dalam bahasa Inggris memetik kata dari bahasa Prancis langue dan dalam bahasa Indonesia "linguistik" adalah nama bidang ilmu dan kata sifatnya adalah "linguistis" atau "linguistik" (Verhaar, 2010).

Sedangkan menurut Mansoer (Pateda, 1991), istilah linguistik dalam bahasa Indonesia berpadanan bersama kata "linguistics" di bahasa Inggris, dan bahasa Inggris mengambil kata serapan "linguistique" yang awalnya dari bahasa Prancis. Istilah linguistik yang digunakan sekarang, sebenarnya berawal dari kata Latin "lingua" yang artinya bahasa. Kata "lingua" pada bahasa Latin masih didapati dalam bahasa serumpun di Eropa, misalnya jika di bahasa Italia "lingua", lalu bahasa Spanyol adalah "lengua", kemudian di bahasa Prancis adalah langue, atau langage. Istilah linguistics pada bahasa Inggris yaitu "the study of languages and language", sementara kata linguis berarti "a person who is clever in foreign languages". Kata langage dalam bahasa Prancis bermakna bahasa pada umumnya, sedangkan kata langue diartikan sebagai bahasa tertentu, contohnya seperti bahasa Indonesia, bahasa Batak, dan bahasa Inggris.

Langacker (1973:5) mengungkapkan sebagai "linguistics is the study of human language" (linguistik adalah bagian dari studi bahasa yang dipakai manusia). Kemudian tokoh ahli Lyons (1975:1) memberi pendapat begini "linguistics may be defined as the scientific study of language". Dengan arti 
lain, linguistik dapat dijelaskan sebagai telaah ilmiah tentang bahasa. Perkara yang lain juga disampaikan oleh Stork dan Widdowson (1985:15) yang mengatakan, "linguistics is the study of language" (linguistik adalah ilmu tentang studi bahasa yang dipakai manusia). Sesuai pengertianpengertian yang telahdipaparkan di atas, peneliti menarik kesimpulan bahwa linguistik adalah melakukan kajian bahasa manusia secara ilmiah. Sehingga yang dapat ditinjau dari linguistik adalah bahasa manusia dan cara menganalisisnya harus secara ilmiah pula.

Dalam kaitannya dengan linguistik dan kajian bahasa, bidang telaah linguistik meliputi struktur internal bahasa/hubungan linguistik dengan struktur bahasa dalam dan struktur eksternal/faktor bahasa yang bergantung pada bahasa eksternal. Secara umum linguistik internal terkait dengan kajian mikrolinguistik, sedangkan kajian eksternal bahasa terkait dengan makrolinguistik. Pertama-tama, objek kajian mikrolinguistik meliputi struktur fonologi, morfologi, sintaksis dan leksikon. Sedangkan fokus kajian makrolinguistik adalah bahasa dalam kaitannya dengan bahasa luar, seperti faktor sosiologis, psikologis, antropologis, dan neurologis. Berkaitan dengan faktor bahasa luar, telah dikembangkan bidang kajian seperti sosiolinguistik, psikolinguistik, neurolinguistik, dan etnolinguistik. Pada penelitian yang dilakukan pada kali ini, peneliti mengambil kajian makrolinguistik yaitu pada bidang kajian sosiolinguistik.

Menurut penjelasan dari Chaer dan Agustina (Agustina, 2010), sosiolinguistik adalah dua interdisipliner ilmu antara sosiologi dan linguistik, dua bidang pengetahuan yang cukup erat hubungannya. Sosiologi mempelajari bagaimana masyarakat sosial dapat bersosialisasi, berlangsung dan tetap ada. Menurut Soerjono Soekanto (Soekanto, 2002), istilah sosiologi berasal dari kata Latin "socius" yang berarti "teman" dan dari kata Yunani "logos" yang berarti "kata" atau "berbicara". Jadi sosiologi berarti "berbicara tentang masyarakat". Sementara itu linguistik merupakan ilmu yang mempelajari bahasa atau bagian ilmu yang mengkaji bahasa sebagai objeknya. Dari sini dapat disimpulkan bahwa sosiolinguistik ialah bidang studi sub-interdisipliner ilmu yang mengeksplorasi bahasa dalam kaitannya dengan pemakaian bahasa itu pada suatu masyarakat.

Rakyat Indonesia adalah rakyat yang menguasai dwibahasa yang sering disebut bilingual, yang diartikan sebagai masyarakat yang memakai dua bahasa atau lebih di suatu kegiatan komunikasi, pada kegiatan berkomunikasi rakyat Indonesia sangat menguasai bahasa Indonesia menjadi bahasa utamanya, namun rakyat Indonesia juga didesak untuk menguasai bahasa asing, khususnya bahasa Inggris. Penguasaan dua bahasa tersebut terkadang digunakan dan diaplikasikan dalam kehidupan sehari-hari secara beriringan, entah disampaikan secara lisan ataupun secara tulisan. Situasi yang demikian dapat memungkinkan terjadinya suatu kontak bahasa yang sama-sama mempengaruhi aktivitas di masyarakatnya. Yang dimaksud saling mempengaruhi disini dapat ditinjau pada penggunaan bahasa oleh individu yang seringkali mencampuri kosakata bahasa asing tak terkecuali bahasa Inggris dengan bahasa Indonesia. Dalam penelitian kali ini, terdapat beberapa pemakaian 
kosakata bahasa Inggris yang digunakan oleh para pemain game online Mobile Legend: Bang-Bang walaupun tidak seluruhnya memakai kosakata bahasa Inggris, namun pengunaan bahasa Indonesia cukup dominan pada data jargon yang peneliti temukan.

Alasan peneliti melakukan penelitian penggunaan jargon ini didasari oleh kurangnya pemahaman antar individu atau kelompok lain di luar dari anak-anak remaja karang taruna Pluto Dalam 2 mengenai bentuk dan makna dari berbagai istilah-istilah atau ujaran kata-kata yang disampaikan. Alasan selanjutnya ialah karena anggota kami merupakan teman satu daerah dari grup tersebut sehingga penelitian ini menjadi lebih mudah dalam menemukan data-data yang dibutuhkan untuk melakukan penelitian ini.

\section{METODOLOGI PENELITIAN}

Pada penelitian ini, peneliti menggunakan penelitian kualitatif dengan cara deskriptif. Menurut Moleong penelitian kualitatif adalah penelitian yang bertujuan untuk mengetahui fenomena tentang apa yang didapati oleh subjek penelitian seperti persepsi, perilaku, tindakan, motivasi, tingkah, dan lainlain (Moleong, 2011: 6). Sebutan deskriptif itu mengusulkan bahwa penelitian yang dilakukan hanya berdasarkan pada fakta-fakta yang sudah ada atau gejala-gejala yang secara empiris sudah hidup pada para penuturnya, sehingga data yang dihasilkan atau yang dicatat berupa serpihan bahasa yang dipaparkan seperti adanya. Bahwa serpihan yang deskriptif tersebut tidak memperhitungkan benar atau salah penggunaan bahasa oleh para penuturnya, dengan begitu itu adalah ciri yang utama (Sudaryanto, 1992). Sedangkan penelitian kualitatif adalah penelitian yang bertujuan untuk mengetahui gejala-gejala tentang apa yang dialami oleh obbjek penelitian, seperti, misalnya persepsi, motivasi, tindakan, dan lain-lain secara berurutan, dengan melakukan deskripsi dalam bentuk kata-kata bahasa, pada suatu konteks khusus yang alamiah dan memanfaatkan berbagai metode ilmiah (Albi Anggito, 2018).

Selanjutnya dalam pengumpulan data, peneliti lakukan dengan teknik simak dan teknik cakap. Teknik simak adalah proses yang digunakan untuk memperoleh data dilakukan dengan cara menyimak pemakain bahasa yang dituturkan oleh penutur. Penyebutan simak di sini bukan saja berkaitan dengan pemakaian bahasa secara lisan saja, tetapi juga pemakaian bahasa secara tertulis. Teknik simak ini memiliki teknik dasarnya, yaitu teknik sadap. Teknik sadap menjadi teknik dasar dalam teknik simak karena pada dasarnya penyimakan diwujudkan dengan tindakan penyadapan. Dalam maksud lain, penelitian dilakukan dalam usaha untuk mendapatkan data yang dilakukan untuk menyadap pemakain bahasa seseorang atau sekelompok orang yang menjadi informannya.

Kemudian pada penelitian ini,dalam langkah selanjutnya penulis memakai teknik sadap lalu diikuti dengan teknik lanjutannya seperti teknik simak libat cakap, teknik simak bebas libat cakap, dan teknik rekam. Teknik simak libat cakap bermaksud peneliti melakukan penyadapan itu dengan cara berinteraksi secara langsung yang dapat dilakukan sambil menyimak, ikut berperan dalam pembicaraan, 
dan menyimak pembicaraan informannya. Dalam hal ini, peneliti terlibat secara langsung dalam dialog yang dilakukan oleh suatu kelompok penutur tertentu. Lalu teknik simak bebas libat cakap dimaksudkan ketika peneliti hanya berperan sebagai pengamat pemakaian bahasa oleh para informannya. Peneliti tidak ikut serta pada peristiwa tuturan yang bahasanya sedang dipahami (Mahsun M, 2005: 92). Kemudian teknik rekam bisa difungsikan jika bahasa yang diteliti adalah bahasa yang masih dituturkan oleh pemiliknya secara terus menerus.

\section{LANDASAN TEORI}

Game online adalah sebuah permainan yang terdapat pada media online seperti komputer, telepon seluler, gadget, tablet, dan jejaring situs online yang bergantung pada internet. Game online biasanya di mainkan untuk melepas penat, mencari kesenangan sejenak, dan sebagai hiburan. Menurut Young (2011: 41) game online merupakan sebuah bentuk hiburan visual yang menggunakan alat seperti gawai, laptop ataupun komputer dan tentunya membutuhkan akses internet dalam memainkannya. Lebih lanjut lagi game online ini dapat di katakan sebagai game yang banyak variasinya, baik dari segi genre ataupun jumlah aturan pemain (Adam \& Rollings, 2010). Banyak sekali faktor hadirnya Game online ini, mulai dari perkembangan zaman yang menuntut semua bisa di akses, terutama dalam mencari kesenangan. Di sisi lain para penggemar game beranggapan bahwa ada kebahagian tersendiri ketika berhasil menyelesaikan misi yang terdapat di game online ini.Kemudian pengertian yang telah dipaparkan kesimpulannya bahwa game online adalah sebuah permainan yang bergantung pada koneksi internet dan media untuk mengaksesnya adalah komputer, gawai, dan media sosial untuk mendapatkan unsur kesenangan dan juga sebagai sarana hiburan bagi yang memainkannya.

Di atas telah di paparkan mengenai pengertian game online, namun kenyataannya game online memiliki banyak jenis-jenisnya. Karena game onlineialahsuatu hiburan visual yang sealaluterkoneksi secara daring ataupun luring dan terhubung dengan pemain di seluruh dunia.

Game online yang sering dimainkan oleh para gamers di seluruh dunia adalah game MMOG (massively multiplayer online game). Jenis MMOG terbagi lagi menjadi: MMORPG (Massively Multiplayer Online Role Playing Game) diantaranya Ragnarok, Seal, Black Desert Mobile, Final Fantasy, dan sebagainya. Lalu MMORTS (Massively Multiplayer Online Real Time Strategy) diantaranya WarCraft, Dota, Mobile Legend, dan League of Legends. Selanjutnya jenis yang terakhir adalah MMOFPS (Massively Multiplayer Online First Person Shooter) diantaranya Grand Theft Auto, Counter Strike, Rising Force, \& Perfect Wars, Player Unknown's Battleground, dan Call of Duty Mobile.

Jenis game online yang menjadi fokus penelitian kali ini adalah game Mobile Legend: Bang Bang. Game online ini tersedia di telepon seluler berbasis Android maupun IOS. Mobile Legend: BangBang adalah game online MOBA/MMORTS yang dirilis oleh perusahaan dan pengembang game 
Moonton sejak tahun 2016. Game ini dapat diakses oleh individu ataupun kelompok dan akan bertemu di satu arena 5 vs 5 . Masing-masing regu yang terdapat 5 orang dibedakan oleh karakter atau hero game yang dipilihnya. Para pemain di tuntut untuk kompak dalam menyesaikan permainan dan tentunya satu misi yaitu bermain seobjektif mungkin, agar meminimalisir waktu sehingga dalam memainkan game ini diperlukan jaringan internet yang stabil, mengolah strategi, mengeluarkan keahlian, kerjasama tim yang kuat, dan komunikasi yang lancar.

Dalam memainkan game online Mobile Legend: Bang-Bang tersebut tentunya dibutuhkan komunikasi yang lancar untuk menyampaikan strategi, penunjuk arah, dan kerjasama tim. Seringkali bahasa yang digunakan saat berkomunikasi adalah bahasa sehari-hari tetapi dicampuri juga dengan bahasa slang dan jargon. Namun ketika sedang memainkan game ini, banyak ujaran maupun dialog tidak bisa di mengerti bagi merekayang tidak memainkan game tersebut. Ujaran bahasa yang disampaikan oleh para pemain Mobile Legend: Bang-Bang ini sifatnya khusus. Sehingga menimbulkan keberagaman suatu ujaran.

Berkenaan dengan keberagaman suatu ujaran yang dituturkan oleh para pemain game online Mobile Legend: Bang-Bang tersebut, peneliti akan memaparkan pengertian variasi bahasa beserta dengan jenis-jenis variasi bahasa.

Variasi atau ragam bahasa merupakan analisis utama dalam telaah sosiolinguistik, Kridalaksana (dalam Chaer dan Agustina, 2010: 61) mengartikan sosiolinguistik sebagai cabang ilmu linguistik yang menjabarkan macam-macam variasi bahasa dan menetapkan pertalian macam-macam variasi bahasa tersebut dengan ciri sosial kemasyarakatan. Kemudian mengutip pendapat dari Fishman (1971: 4) Kridalaksana mengemukakan bahwa sosiolinguistik adalah ilmu yang membahas ciri dan fungsi berbagai jenis variasi bahasa, serta adanya hubungan di antara bahasa dengan ciri dan fungsi itu dalam suatu masyarakat bahasa.

Sebagai suatu bahasa, bahasa memiliki sistem dan subsistem yang dapat dipahami secara merata oleh semua penutur bahasa tersebut. Akan tetapi, karena penutur bahasa ini, sekalipun mereka adalah bagian dari masyarakat tutur, bukan merupakan kumpulan orang yang homogen, maka bentuk konkret bahasa itu, yang kita sebut parole, jadi tidak seragam. Bahasa menjadi beragam dan bervariasi. Munculnya keragaman atau variasi kebahasaan ini tidak hanya disebabkan oleh penutur yang tidak homogen, tetapi juga karena aktivitas interaksi sosial yang mereka lakukan sangat berbeda dan juga bagi manusia multibahasa yang sangat terbuka terhadap bahasa lain. Setiap kegiatan membutuhkan dan menyebabkan keragaman bahasa. Keanekaragaman ini akan bertambah jika bahasa tersebut digunakan oleh penutur dalam jumlah yang banyak dan dalam wilayah yang sangat luas (Chaer dan Agustina. 2010: 61).

Berkenaan dengan variasi atau ragam bahasa, ada dua sudut pandang yang bertentangan, pertama bahwa variasi atau ragam bahasa dipandang sebagai akibat dari keanekaragaman sosial penutur 
bahasa itu dan keanekaragaman fungsi bahasa itu. Variasi atau ragam bahasa oleh karenanya timbul sebagai akibat dari keragaman sosial dan keragaman fungsi kebahasaan. Jika penutur bahasa ini merupakan kelompok yang homogen, baik menurut suku, status sosial dan bidang pekerjaan, maka tidak ada variasi atau keragaman, sehingga bahasa menjadi seragam. Dan yang kedua adalah variasi atau keragaman bahasa yang sudah ada untuk memenuhi fungsinya sebagai sarana interaksi dalam berbagai aktivitas masyarakat. Kedua pandangan bisa diterima atau ditolak. Sudah jelas bahwa keragaman atau fungsi kegiatan dalam sejumlah besar komunitas bahasa sosial dapat diklasifikasikan menurut keberadaan keragaman sosial (Chaer dan Agustina, 2010: 62). Mengenai keanekaragaman sosial dan keanekaragaman kebahasaan yang terjadi dalam masyarakat bahasa, berikut ini diuraikan secara rinci jenis-jenis variasi kebahasaan, yang dibagi menjadi empat jenis, yaitu variasi bahasa dari segi pemakaian, variasi bahasa dari segi keformalan, variasi bahasa dari segi sarana dan variasi bahasa dari segi penutur.

Pertama, variasi bahasa dilihat melalui segi pemakaian. Menurut pendapat Nababan (dalam Chaer dan Agustina, 2010: 68) variasi bahasa dari segi pemakaian bisa ditinjau dari segi penggunaannya, pemakaiannya, atau fungsi-fungsinya yang biasanya disebut fungsiolek, ragam, atau register. Variasi ini pada umumnya dilihat berdasarkan bidang penggunaan, gaya, atau tingkat keformalan, dan sarana penggunaan. Contoh dari variasi bahasa berdasarkan pemakaian ini yang menyangkut bahasa itu digunakan untuk keperluan atau bidang apa. Seperti, misalnya, bidang sastra jurnalistik, militer, pelayaran, perekonomian, perdagangan, pendidikan, dan lain-lain.

Kedua, variasi bahasa dilihat melalui segi keformalan. Martin Joos (1967, dalam Chaer dan Agustina, 2010: 70) dalam bukunya The Five Clock mengkategorikan variasi bahasa yang ditinjau dari keformalannya terbagi atas lima macam gaya atau dalam bahasa Inggris style, yang diantaranya ragam beku, ragam resmi (formal), ragam usaha (konsultasi), ragam santai (kasual), dan gaya atau ragam akrab (intimate).

Ragam beku merupakan variasi bahasa yang sangat formal, biasanya digunakan dalam situasisituasi khusyuk, dan upacara-upacara yang resmi, seperti misalnya, dalam upacara kenegaraan, khutbah di masjid-masjid, pengambilan sumpah serapah, kitab undang-undang, akta notaris, dan lain-lain (Chaer dan Agustina, 2010: 70).

Ragam resmi atau sering disebut formal merupakan variasi bahasa yang dipakai dalam pidato presiden atau kenegaraan, rapat menteri, surat-menyurat dinas, ceramah keagamaan, yang selanjutnya ditetapkan secara mantap sebagai suatu standar pemakaian. Ragam resmi ini pada umumnya sama seperti ragam bahasa baku atau standar yang hanya digunakan dalam situasi-situasi resmi saja (Chaer dan Agustina, 2010: 70-71).

Ragam usaha merupakan variasi bahasa yang seringkali dipakai dalam komunikasi biasa di sekolah-sekolah, dan rapat-rapat penting atau pembicaraan yang berorientasi kepada hasil atau 
produksi. Sehingga bisa dikatakan ragam usaha ini ialah ragam bahasa yang sangat operasional. Bentuk ragam usaha ini berada di dua sisi antara ragam formal dan ragam informal atau ragam santai (Chaer dan Agustina, 2010: 71).

Ragam santai merupakan variasi bahasa yang dipakai pada situasi tidak resmi untuk berbicara bersama keluarga atau teman dekat pada aktivitas olahraga, sambil beristirahat, berbincang-bincang, berekreasi, dan lain-lain. Ragam santai ini banyak menggunakan bentuk alegro, yakni bentuk kata atau ujaran yang dipendekkan (Chaer dan Agustina, 2010: 71).

Ragam akrab merupakan variasi bahasa yang sering dipakai oleh para penutur dan mitra tutur yang hubungan keduanya sudah akrab, seperti antar anggota keluarga, dan antar teman maupun sahabat yang sudah sangat akrab. Ragam ini diberi tanda oleh pemakaian bahasa yang tidak lengkap, hanya pendek-pendek saja, dan dengan artikulasi yang acapkali tidak jelas (Chaer dan Agustina, 2010: 71).

Ketiga, variasi bahasa dilihat melalui segi sarana. Variasi bahasa bisa juga ditinjau dari segi sarana atau jalur-jalur yang digunakan saat dituturkan. Dalam maksud lain disebut adanya ragam lisan dan ragam tulisan, atau juga ragam dalam berbahasa dengan memakai sarana atau alat-alat tertentu, seperti misalnya dalam telepon dan mengirim telegraf. Kemunculan ragam bahasa lisan dan ragam bahasa tulis didasari pada realita bahwa bahasa lisan dan bahasa tulis memiliki bentuk dan struktur yang tidak sama (Chaer dan Agustina, 2010: 72).

Keempat, variasi bahasa dilihat melalui segi penutur. Untuk variasi bahasa pertama yang bisa dilihat sesuai penuturnya adalah variasi bahasa yang disebut idiolek, yakni variasi bahasa yang bersifat perseorangan. Idiolek ini memiliki konsep, setiap individu mempunyai variasi bahasanya atau idioleknya masing-masing. Variasi idiolek ini berkaitan dengan "warna" suara, diksi, gaya bahasa, susunan kalimat, kata-kata, dan lain-lain.

Variasi bahasa kedua berdasarkan penuturnya adalah yang disebut dialek, yakni variasi bahasa dari sekelompok penutur yang jumlahnya relatif, terbatas pada satu wilayah saja, di satu tempat, atau zona-zona tertentu saja. Oleh sebab dialek ini dibatasi pada wilayah atau zona tempat tinggal penutur, maka dialek ini seringkali disebut dialek areal, dialek regional atau dialek geografi. Para penutur dalam suatu dialek, meskipun mereka mempunyai idioleknya masing-masing, memiliki kesamaan ciri yang menunjukkan bahwa mereka berada di satu dialek, dan berbeda dengan kelompok-kelompok penutur lain, yang berada dalam dialeknya sendiri dengan ciri lain yang menandai dialeknya juga (Chaer dan Agustina, 2010: 63).

Variasi bahasa ketiga berdasarkan penutur adalah yang disebut kronolek atau dialek temporal, yakni variasi bahasa yang digunakan oleh kelompok sosial pada masa tertentu. Misalnya, variasi bahasa Indonesia pada masa tahun tiga puluhan, variasi yang dipakai tahun lima puluhan, dan variasi yang digunakan pada masa kini (Chaer dan Agustina, 2010: 63). 
Variasi bahasa keempat berdasarkan penuturnya biasanya disebut sosiolek atau dialek sosial, yakni variasi bahasa yang berkaitan langsung dengan kedudukan, golongan, dan kelas sosial para penuturnya. Dalam kajian sosiolinguistik biasanya variasi inilah yang paling banyak dibicarakan dan paling banyak menyita waktu untuk membicarakannya, karena variasi ini menyangkut semua masalah pribadi para penuturnya, seperti usia, pendidikan, seks, pekerjaan, tingkat kebangsawanan, keadaan sosial ekonomi, dan sebagainya. Sehubungan dengan variasi bahasa berkenaan dengan tingkat, golongan, status, dan kelas sosial para penuturnya, biasanya sering diartikan oleh orang diantaranya variasi bahasa yang disebut akrolek, basilek, vulgar, slang, kolokial, jargon, argot dan ken. Ada juga yang menambahkan dengan yang disebut bahasa prokem (Chaer dan Agustina, 2010: 64).

Yang dimaksud dengan akrolek adalah variasi sosial yang dianggap lebih tinggi atau lebih bergengsi daripada variasi sosial lainnya.

Yang dimaksud dengan basilek adalah variasi sosial yang dianggap kurang bergengsi, atau bahkan dianggap dipandang rendah. Bahasa Inggris yang digunakan oleh para koboi dan pekerja tambang dapat dikatakan sebagai basilek.

Yang dimaksud dengan vulgar adalah variasi sosial yang ciri-cirinya tampak pemakaian bahasa oleh mereka yang kurang terpelajar, atau dari kalangan mereka yang tidak berpendidikan. Pada zaman Romawi sampai zaman pertengahan bahasa-bahasa di Eropa dianggap sebagai bahasa vulgar, sebab pada waktu itu para golongan intelek menggunakan bahasa Latin dalam segala kegiatan mereka.

Yang dimaksud dengan slang adalah variasi sosial yang bersifat khusus dan rahasia. Artinya, variasi ini digunakan oleh kalangan tertentu yang sangat para terbatas, dan tidak boleh diketahui oleh kalangan di luar kelompok itu. Oleh karena itu, kosakata yang digunakan dalam slang ini selalu berubah-ubah.

Yang dimaksud dengan kolokial adalah variasi sosial yang digunakan dalam percakapan seharihari. Kata kolokial berasal dari kata 'colloquium' yang artinya percakapan. Jadi, kolokial berarti bahasa percakapan, bukan bahasa tulis. Juga tidak tepat kalau kolokial ini disebut bersifat "kampungan" atau bahasa kelas golongan bawah, sebab yang penting adalah konteks dalam pemakaiannya.

Yang dimaksud dengan argot adalah variasi bahasa sosial yang digunakan secara terbatas pada profesi-profesi tertentu dan bersifat rahasia. Letak kekhususan argot adalah kosakata. Yang dimaksud dengan ken adalah variasi bahasa sosial tertentu yang bernada "memelas", sengaja dibuat merengekrengek, meminta belas kasihan, dan penuh dengan kepura-puraan.

Selanjutnya, pada penelitian kali ini akan dijelaskan secara rinci mengenai pengertian jargon berdasarkan pendapat ahli, sekaligus juga menjadi tema pembahasan khusus yang telah kami lakukan penelitian yaitu penggunaan jargon. 
Yang dimaksud dengan jargon adalah variasi sosial yang digunakan secara terbatas oleh kelompok-kelompok sosial tertentu. Ungkapan yang digunakan seringkali tidak dapat dipahami oleh masyarakat umum atau masyarakat di luar kelompoknya. Namun, ungkapan-ungkapan tersebut tidak bersifat rahasia (Chaer dan Agustina, 2010).

Menurut Gorys Keraf, jargon mengandung beberapa pengertian. Pertama jargon diartikan sebagai makna suatu bahasa, dialek, atau tutur yang dianggap kurang sopan atau aneh. Tetapi istilah itu dipakai juga untuk mangacu semacam bahasa atau dialek hibrid yang timbul dari percampuran bahasabahasa, dan sekaligus dianggap sebagai bahasa perhubungan atau lingua franca. Makna yang ketiga mempunyai ketumpangtindihan dengan bahasa ilmiah. Dalam hal ini, jargon diartikan sebagai kata-kata teknis atau rahasia dalam suatu bidang ilmu tertentu, dalam bidang seni, perdagangan, kumpulan rahasia, atau kelompok-kelompok khusus lainnya. Oleh karena jargon merupakan bahasa yang khusus sekali, maka tidak akan banyak artinya bila dipakai untuk suatu sasaran yang umum. Sebab itu, hendaknya dihindari sejauh mungkin unsur jargon dalam sebuah tulisan umum (Keraf, 2010: 107).

\section{PEMBAHASAN}

Pembahasan dalam penelitian kali ini akan dijelaskan secara harfiah berdasarkan hasil bentuk kata atau istilah yang diujarkan beserta dengan makna bahasa pada penggunaan bahasa jargon. Dalam penelitian ini kami menggunakan objek yang berasal dari peristiwa ujaran yang terdapat di lingkungan remaja karang taruna Pluto Dalam 2 Pisangan Tangerang Selatan. Data-data yang telah kami kumpulkan didapatkan dengan cara menyimak ujaran dan komunikasi mereka ketika sedang memainkan game Mobile Legend: Bang-Bang tersebut.

\begin{tabular}{|l|l|l|}
\hline Data & Nama Jargon & Makna Bahasa \\
\hline 1. & Retri indomaret & $\begin{array}{l}\text { Istilah 'retri adalah kepanjangan dari } \\
\text { 'retribution' dan dalam bahasa Indonesia } \\
\text { berarti artinya "ganjaran". Sedangkan } \\
\text { Indomaret merujuk kepada warna mantra } \\
\text { yang ada didalam game. } \\
\text { Istilah ini digunakan bagi seorang penyerang } \\
\text { yang terfokus untuk membunuh satu karakter } \\
\text { tetapi penyerang tersebut gagal } \\
\text { membunuhnya dan penggunaan kemampuan } \\
\text { atau kekuatan tambahan tidak tepat. }\end{array}$ \\
\hline $\mathbf{2 .}$ & Noob & $\begin{array}{l}\text { Kata "noob" sendiri merupakan bahasa slang } \\
\text { dari "newbie" yang jika dalam bahasa } \\
\text { Indonesia artinya yaitu pemain baru dan tidak } \\
\text { berpengalaman. } \\
\text { Istilah "newbie" ini ditujukan untuk } \\
\text { menyindir seseorang yang bermainnya masih } \\
\text { kaku, bermain dengan tidak benar, dan cupu. }\end{array}$ \\
\hline 3. & Di gendong & $\begin{array}{l}\text { Istilah "di gendong" ini bermakna sebagai } \\
\text { pemain yang sangat jago dan pintar ingin } \\
\text { menggendong serta mengajari pemain yang } \\
\text { tidak memiliki kemampuan yang mumpuni. }\end{array}$ \\
\hline
\end{tabular}




\begin{tabular}{|c|c|c|}
\hline 4. & Foto bareng & $\begin{array}{l}\text { Istilah "foto bareng" seringkali bermakna } \\
\text { sebagai foto yang dilakukan beramai-ramai } \\
\text { pada suatu tempat. } \\
\text { Namun dalam game ini istilah tersebut } \\
\text { bermakna sebagai berkumpul bersama antara } \\
\text { satu tim dengan tim lawan kemudian } \\
\text { melakukan tangkapan layar di dalam game. }\end{array}$ \\
\hline 5. & NF (No Flicker) & $\begin{array}{l}\text { Istilah "flicker" jika dalam bahasa Indonesia } \\
\text { adalah "kedipan". } \\
\text { Namun dalam game ini istilah "flicker" } \\
\text { diartikan sebagai mantra khusus yang } \\
\text { berfungsi untuk melakukan inisiasi ke arah } \\
\text { lawan atau untuk melarikan diri. Tetapi } \\
\text { mantra khusus ini tidak tersedia kemampuan } \\
\text { tambahan dalam waktu tertentu. }\end{array}$ \\
\hline 6. & Nggak Ada Obat & $\begin{array}{l}\text { Makna dari kata "nggak ada obat" pada game } \\
\text { ini sendiri adalah ketika seorang pemain } \\
\text { bermain dengan sangat baik, penerapan } \\
\text { strategi yang bagus, dan juga sangat } \\
\text { memahami betul kelemahan karakter lawan. }\end{array}$ \\
\hline 7. & Mabar & $\begin{array}{l}\text { Istilah "mabar" sendiri adalah akronim dari } \\
\text { kepanjangan "main bareng", sehingga istilah } \\
\text { ini digunakan untuk memberi ajakan bermain } \\
\text { bersama antara dua, tiga, atau lima orang } \\
\text { untuk menyelesaikan misi yang terdapat di } \\
\text { dalam game. }\end{array}$ \\
\hline 8. & Tank & $\begin{array}{l}\text { Istilah "tank" dalam dunia nyata adalah suatu } \\
\text { kendaraan perang yang berfungsi sebagai } \\
\text { perusak, penghancur, dan pembunuh bagi } \\
\text { lawan-lawannya. } \\
\text { Namun dalam game ini istilah "tank" } \\
\text { merujuk kepada pemakaian salah satu } \\
\text { karakter dalam membuka peta atau } \\
\text { peperangan sekaligus juga berfungsi sebagai } \\
\text { pelindung dan penahan serangan yang } \\
\text { diposisikan pada bagian belakang. }\end{array}$ \\
\hline 9. & Tower & $\begin{array}{l}\text { Istilah "tower" jika dalam bahasa Indonesia } \\
\text { adalah "menara". Dalam kehidupan sehari- } \\
\text { hari menara berarti bangunan yang dibuat dan } \\
\text { dibangun secara tinggi dan biasanya memiliki } \\
\text { lantai yang banyak. } \\
\text { Namun dalam game Moblie Legend ini kata } \\
\text { "tower" bermakna sebagai menara pelindung, } \\
\text { benteng pertahanan untuk berlindung dari } \\
\text { serangan lawan. }\end{array}$ \\
\hline 10. & Monster hutan & $\begin{array}{l}\text { Istilah "monster hutan" seringkali diartikan } \\
\text { sebagai makhluk yang menakutkan, makhluk } \\
\text { yang berukuran besar dan raksasa yang } \\
\text { bentuknya menyimpang dari biasanya dan } \\
\text { tinggal di dalam hutan. } \\
\text { Namun dalam game Mobile Legend ini } \\
\text { bermakna sebagai monster yang membantu } \\
\text { tim untuk mendapatkan emas yang } \\
\text { berlimpah, apabila monster ini dibunuh maka }\end{array}$ \\
\hline
\end{tabular}




\begin{tabular}{|c|c|c|}
\hline & & $\begin{array}{l}\text { karakter yang membunuh monster tersebut } \\
\text { akan mendapatkan pertahanan diri yang kuat } \\
\text { sekaligus juga sebagai penentu dalam } \\
\text { kemenangan tim. }\end{array}$ \\
\hline 11. & Tremor & $\begin{array}{l}\text { Istilah ini biasanya diartikan sebagai getaran } \\
\text { yang terjadi pada tangan akibat melakukan } \\
\text { aktivitas yang berat dalam jangka waktu yang } \\
\text { lama dan bermain game tanpa jeda sehingaa } \\
\text { terjadi gangguan pada syaraf tangan yang } \\
\text { sulit dikendalikan. }\end{array}$ \\
\hline 12. & Kena mental & $\begin{array}{l}\text { Istilah ini seringkali diucapkan dan dimaknai } \\
\text { oleh para pemain untuk memberi sindiran } \\
\text { kepada pemain lain dan tim lawan akibat } \\
\text { sering mati karena kalah duel satu lawan satu } \\
\text { sehingga menyebabkan satu tim kalah dan } \\
\text { membuat posisi tim sedang tertekan. }\end{array}$ \\
\hline 13. & Sergapan & $\begin{array}{l}\text { Istilah ini mempunyai makna untuk } \\
\text { melakukan serangan secara tiba-tiba, secara } \\
\text { serentak, dan serangan tersebut dilakukan } \\
\text { bersama satu tim. }\end{array}$ \\
\hline 14. & Ultimate & $\begin{array}{l}\text { Istilah "ultimate" jika dalam bahasa } \\
\text { Indonesia adalah penghabisan, pamungkas, } \\
\text { atau terakhir. } \\
\text { Namun dalam game Mobile Legend ini } \\
\text { dimaknai sebagai skill pamungkas yang } \\
\text { dikeluarkan suatu karakter untuk melakukan } \\
\text { serangan secara masif. Jurus atau kekuatan } \\
\text { yang terdapat pada karakter ini menjadi } \\
\text { kekuatan untuk mematikan musuh. }\end{array}$ \\
\hline 15. & Farming & $\begin{array}{l}\text { Istilah "farming" jika diartikan ke dalam } \\
\text { bahasa Indonesia adalah pertanian. } \\
\text { Namun dalam game Mobile Legend ini, } \\
\text { istilah "farming" dimaknai sebagai salah satu } \\
\text { proses untuk mengumpulkan sumber daya } \\
\text { sebanyak-banyaknya selama permainan } \\
\text { berlangsung, pencarian sumber daya yang } \\
\text { dimaksud adalah merampok emas dan poin } \\
\text { yang terdapat pada monster hutan. Setelah } \\
\text { mengumpulkan sumber daya yang cukup, } \\
\text { hasil rampasan akan digunakan untuk } \\
\text { membeli item yang ada di dalam game. }\end{array}$ \\
\hline 16. & Adu mekanik & $\begin{array}{l}\text { Istilah ini dimaknai sebagai cara kerja } \\
\text { karakter di dalam game dan pemainnya untuk } \\
\text { melakukan duel satu lawan satu. Mekanik } \\
\text { berhubungan dengan kecepatan jari pemain } \\
\text { sampai kemampuan pemain dalam } \\
\text { menempatkan posisi, sehingga pemain } \\
\text { dituntut harus memprediksikan pergerakan } \\
\text { lawan serta menggunakan mantra dan skill di } \\
\text { waktu yang tepat dalam duel satu lawan satu } \\
\text { dengan pemain lawan. }\end{array}$ \\
\hline 17. & Combo & $\begin{array}{l}\text { Istilah "combo" jika diartikan ke dalam } \\
\text { bahasa Indonesia adalah kombinasi dari } \\
\text { beberapa komponen. }\end{array}$ \\
\hline
\end{tabular}




\begin{tabular}{|l|l|l|}
\hline & $\begin{array}{l}\text { Sedangkan istilah kombo yang terdapat pada } \\
\text { game Mobile Legend dimaknai sebagai } \\
\text { pemakaian dua mantra secara bersama-sama } \\
\text { untuk menciptakan efek yang sangat } \\
\text { mematikan bagi lawan-lawannya. }\end{array}$ \\
\hline
\end{tabular}

\section{SIMPULAN}

Berdasarkan deskripsi hasil data dari penelitian yang sudah dipaparkan di atas, dapat disimpulkan bahwa penggunaan jargon oleh anak remaja karang taruna Pluto Dalam 2 Pisangan Tangerang Selatan meliputi penggunaan bahasa jargon, bentuk, dan makna dari jargon tersebut.

Keseluruhan jargon yang didapatkan pada penelitian ini yaitu sebanyak 17 jargon, diantaranya: 1) retri indomaret; 2) noob; 3) di gendong; 4) foto bareng; 5) no flicker; 6) nggak ada obat; 7) mabar; 8) tank; 9) tower; 10) monster hutan; 11) tremor; 12) kena mental; 13) sergapan; 14) ultimate; 15) farming; 16) adu mekanik; dan 17) combo. Penggunaan jargon oleh para remaja karang taruna Pluto Dalam 2 Pisangan Tangerang Selatan ini memiliki fungsi diantaranya untuk memudahkan komunikasi antar pemain, untuk mengetahui istilah-istilah bahasa yang hanya dipahami oleh mereka ketika memainkan game tersebut, dan juga untuk menambah keakraban antar pemain Mobile Legend: BangBang. Dengan adanya penelitian jargon seperti ini, setidaknya dapat memperkaya kosakata, istilahistilah, dan memberi sedikit pembaharuan dalam perkembangan variasi bahasa terutama untuk masyarakat yang tidak terikat oleh sekumpulan remaja ini.

\section{DAFTAR PUSTAKA}

Agustina, A. C. (2010). Sosiolinguistik: Perkenalan Awal. Jakarta: Rineka Cipta.

Albi Anggito, J. S. (2018). Metodologi Penelitian Kualitatif. Sukabumi: CV Jejak.

Alwasilah, C. (1985). Bebarapa Madhab dan lokotomi Teori Linguistik. Bandung : Angkasa Bandung Keraf, G. (2010). Diksi dan Gaya Bahasa. Jakarta: PT Gramedia Pustaka Utama.

Mahsun M, S. (2005). Metode Penelitian Bahasa: Tahapan, Strategi, Metode, dan Tekniknya (Ketiga ed.). Depok: Rajawali Press.

Moleong, L. J. (2011). Metodologi Penelitian Kualitatif. Bandung : Remaja Rosadakarya.

Pateda, M. (1991). Linguistik Terapan. Yogyakarta: Nusa Indah Yogyakarta.

Ramadansyah. (2010). Paham dan Terampil Berbahasa dan Bersastra Indonesia. Bandung: Dian Aksara Press.

Soekanto, S. (2002). Sosiologi Suatu Pengantar. Jakarta: RajaGrafindo Persada.

Sudaryanto. (1992). Metode Linguistik: Ke Arah Memahami Metode Linguistik. Gadjah Mada University Press.

Verhaar, J. (2010). Asas-asas Linguistik Umum. Yogyakarta: Gadjah Mada University Press. 